\title{
Diagenetic behavior of barite in a coastal upwelling setting
}

\author{
I. L. Hendy ${ }^{1}$ \\ Received 13 November 2009; revised 28 July 2010; accepted 19 August 2010; published 14 December 2010.
}

[1] Multiproxy data from ODP Hole 1017E (Point Conception, California) provide an excellent opportunity to examine the behavior of barium, within a well-characterized sedimentary system. Barium excess $_{\text {is generally }}$ considered to be a productivity proxy; however, in nearshore environments, $\mathrm{Ba}_{\text {excess }}$ records can be compromised by both sediment provenance and barite remobilization. For the last $60 \mathrm{kyr}$, ODP Hole 1017E exhibits significant changes both in primary productivity driven by coastal upwelling and in the sediment redox chemistry of underlying sediments. Significant barite enrichment occurs at an active diagenetic front that marks the boundary between sulfate-rich and sulfate-poor pore waters. This boundary also intersects a sediment facies change from deposition of relatively coarse-grained sediment before $35 \mathrm{ka}$ to an interval of fine-grained, organic-rich sediment after (i.e., Interstadial Event 8). Changes in diffusion rates associated with the sediment facies change cause a strong but misleading correlation between a mobile zone of barite enrichment and rapid climate change. Thus, within the $\mathrm{Ba}_{\text {excess }}$ record at ODP Hole $1017 \mathrm{E}$ is a history of redox chemistry that has corrupted the paleoproductivity record of $\mathrm{Ba}_{\text {biogenic }}$.

Citation: Hendy, I. L. (2010), Diagenetic behavior of barite in a coastal upwelling setting, Paleoceanography, 25, PA4103, doi:10.1029/2009PA001890.

\section{Introduction}

[2] A common assumption in sedimentology is that stratigraphic position determines age relationships such that material within the same stratum is of equivalent age [Steno and Winter, 1916]. This principle often extends to the correlation between potentially mobile elements and sedimentary particles. Associated with decaying organic matter (Corg) in ocean water, marine barite $\left(\mathrm{BaSO}_{4}\right)$ is a major carrier of particulate barium to the seafloor and thus $\mathrm{Ba}$ has been directly related to marine Corg sedimentation [Bishop, 1988; Ganeshram et al., 2003; Goldberg and Arrhenius, 1958; Paytan and Griffith, 2007]. Ba concentration corrected for the presence of detrital $\mathrm{Ba}\left(\mathrm{Ba}_{\text {excess }}\right)$ has been shown to be a reasonable proxy of past changes in oceanic productivity in well-oxygenated deep sea sediments dominated by biogenic sediments and with minimal terrigenous sediment input [Eagle et al., 2003]. Paleoproductivity reconstructions where $\mathrm{Ba}$ has been used as a proxy include the Last Glacial Maximum in equatorial upwelling systems] Paytan and Kastner, 1996], sapropel formation in the Mediterranean [Weldeab et al., 2003], and at the PaleoceneEocene Thermal Maximum [Bains et al., 2000; Paytan et al., 2007].

[3] However, it is not reasonable to assume $\mathrm{Ba}_{\text {biogenic }}$ is equivalent to $\mathrm{Ba}_{\text {excess }}$ in every marine environment. $\mathrm{Ba}_{\text {biogenic }}$ is an interpretation that assumes that all $\mathrm{Ba}$ concentrations higher than estimated detrital input are the product of marine

\footnotetext{
${ }^{1}$ Department of Geological Sciences, University of Michigan, Ann Arbor, Michigan, USA.

Copyright 2010 by the American Geophysical Union. 0883-8305/10/2009PA001890
}

Corg sedimentation (marine barite). Implicit in this assumption is that sources and delivery of detrital sediment remain constant through time. Furthermore, there are still unconstrained issues associated with $\mathrm{Ba}_{\text {excess }}$, including the precise carrying phase of the element and the significance of diagenetic remobilization. $\mathrm{Ba}$ in aluminosilicate phases (i.e., lithogenic $\mathrm{Ba})$ is typically immobile, while barite $\left(\mathrm{BaSO}_{4}\right)$ is extremely susceptible to dissolution under suboxic to anoxic conditions [Brumsack, 1986; van Os et al., 1991]. The solubility of barite in sediments remains low until sulfate depletion begins. As depletion of sulfate continues, the solubility of barite increases significantly, resulting in barite dissolution and higher dissolved Ba concentrations within the sediment pore waters [McManus et al., 1998; Torres et al., 1996]. In continental margin settings where there is significant detrital input and high oxidant demand for Corg respiration, the use of $\mathrm{Ba}_{\text {excess }}$ as a proxy for paleoproductivity reconstruction is problematic. Thus understanding the history of sediment redox conditions and detrital sediment delivery is crucial for an accurate interpretation of $\mathrm{Ba}$ as a paleoproductivty proxy.

[4] ODP Hole 1017E, $\left(34^{\prime} 32^{\prime \prime} \mathrm{N}, 121^{\prime} 6^{\prime \prime} \mathrm{W}\right.$; $956 \mathrm{~m}$ water depth), $\sim 60 \mathrm{~km}$ to the west of Point Conception, on the Southern California Margin provides an ideal location to examine complications associated with the sedimentary $\mathrm{Ba}$ record. This site lies beneath a persistent modern upwelling cell and has yielded high-resolution paleoclimate records due to significant terrestrial sediment input [Cannariato and Kennett, 1999; Irino and Pedersen, 2000; Kennett et al., 2000; Tada et al., 2000]. Bottom water oxygen concentrations at ODP Hole 1017E have fluctuated through time due to its position in the lower oxygen minimum zone (OMZ) and high Corg rain rates from overlying productive surface waters. Presently the $\mathrm{OMZ}$ is a significant feature along the 


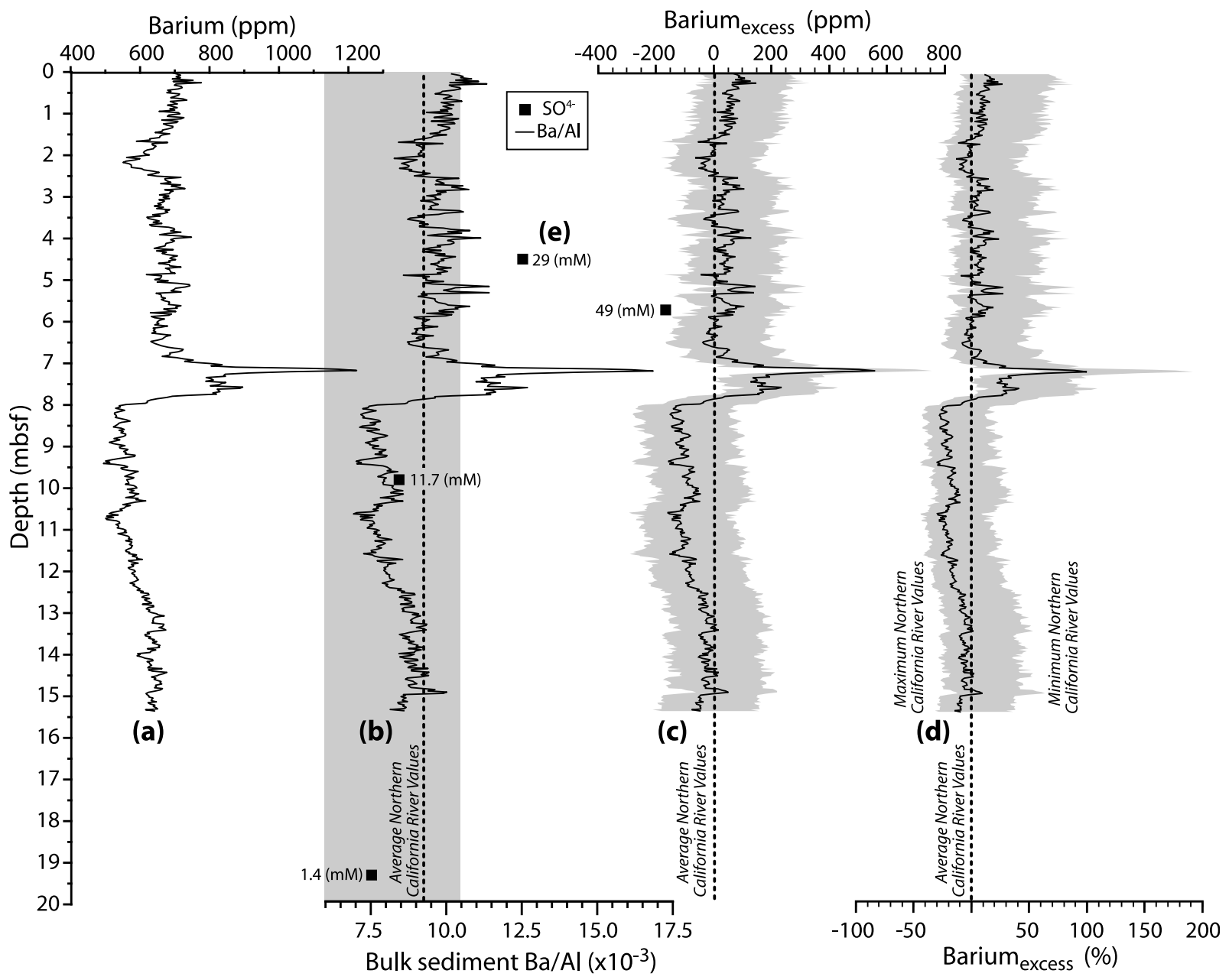

Figure 1. Comparison of the concentration of (a) total barium (ppm) relative to (b) aluminum and (c) barium excess $_{(\mathrm{ppm}) \text {, and (d) barium }}$ excess as a percent value of detrital Ba with (e) pore water sulfate concentrations (square symbols with concentrations indicated) at ODP Hole 1017E. Gray shading indicates the maximum and minimum values of northern California rivers, while the dashed line represents the average value.

California Margin; however, during the last glacial, waxing and waning of the OMZ has been recorded both at this site and others [Cannariato and Kennett, 1999; Zheng et al., 2000].

[5] Multiproxy results from ODP Hole 1017E have allowed researchers both to determine the history of past productivity changes as well as understanding the redox chemistry of the sediments [Cannariato and Kennett, 1999; Hendy et al., 2004; Hendy and Pedersen, 2005; Irino and Pedersen, 2000; Seki et al., 2002; Tada et al., 2000]. Here the record of $\mathrm{Ba}_{\text {excess }}$ is presented, demonstrating how the history of marine barite preservation was compromised at the site. However, unexpectedly the position of an active diagenetic front appears to be predetermined by the paleoproductivity and paleohydrodynamic history of the site. Thus, a significant quantity of mobile Ba has precipitated within sediments associated with a known climatic event (Interstadial Event 7), producing a pronounced $\mathrm{Ba}_{\text {excess }}$ peak that could simply be misinterpreted as $\mathrm{Ba}_{\text {biogenic }}$ associated with climatically driven high ocean productivity.

\section{Methods}

[6] Concentrations of $\mathrm{Ba}$ (Figure 1a) were determined for 337 samples from 5.9 to 15.4 mbsf using a Phillips PW $24000 \mathrm{X}$-ray spectrometer equipped with a $3 \mathrm{Kw} \mathrm{Rh}$ tube following standard methods [Calvert, 1983; van Geen et al., 1996]. All other major and minor elements, trace metals and productivity proxies are discussed in detail by Hendy et al. [2004] and Hendy and Pedersen [2005]. Ba levels above the detrital background recorded in Northern California rivers of $\sim 500 \mathrm{ppm}$ or $\mathrm{Ba} / \mathrm{Al}$ ratios of 0.0092 (Figure $1 \mathrm{~b}$ ) [Dean et al., 1997] were calculated using the following formula [Paytan and Griffith, 2007]:

$$
\mathrm{Ba}_{\text {excess }}=\mathrm{Ba}_{\text {sample }}-\left((\mathrm{Ba} / \mathrm{Al})_{\text {background }} \times \mathrm{Al}_{\text {sample }}\right)
$$


[7] $\mathrm{Ba}_{\text {excess }}$ is displayed in Figure 1 as both $\mathrm{Ba}_{\text {excess }}(\mathrm{ppm})$ (Figure 1c) and $\mathrm{Ba}_{\text {excess }}(\%)$ (Figure 1d) with shading to display maximum and minimum values spanning the range of Ba concentrations found in California rivers. This highlights the potential influence of changes in the terrigenous provenance of detrital input.

[8] Major and minor element distributions has been related to grain size at ODP Hole 1017E [Irino and Pedersen, 2000; Tada et al., 2000]. Major and minor element data were simplified by a Q-mode factor analysis with varimax rotation using the computer program $\mathrm{CABFAC}$ to provide factors that describe the distribution of elements known to be associated with different grain sizes [Imbrie and Kipp, 1971; Leinen and Pisias, 1984]. Two factors explaining 97.3\% of the total variance were extracted from the data set with communalities mostly $>0.95$. Loading in factor 1 ( $54.4 \%$ of total variance) is dominated by $\mathrm{Ni}, \mathrm{Cu}, \mathrm{Zn}, \mathrm{Fe}, \mathrm{Mg}$ and $\mathrm{Ca}$. These elements are often associated with the clay fraction. Factor $2(42.9 \%$ of the total variance) loading is influenced by $\mathrm{Zr}, \mathrm{Si}, \mathrm{Na}$, and $\mathrm{K}$. These elements are frequently found in larger (silt-sand) grains [Hendy et al., 2004]. These interpretations are supported by grain size analysis at the site [Irino and Pedersen, 2000; Tada et al., 2000].

[9] Chronology presented in this contribution is discussed in greater detail by Hendy et al. [2004]. The climatic event dates are based on the correlation of $N$. pachyderma coiling ratios between ODP Hole 893A and 1017E as described by Hendy [2010]. The chronology of ODP Hole 893A is described by Hendy et al. [2002] and interstadials (IS) 5 to 17 are assumed to be synchronous with interstadial events in the GISP2.

\section{Sedimentary Barium Record at Point Conception}

[10] $\mathrm{Ba}_{\text {excess }}$ is used to describe $\mathrm{Ba}$ concentrations in sediments that exceed detrital input, which is assumed to be constant through time, and as such this term does not constrain the origin of $\mathrm{Ba}$. The $\mathrm{Ba}_{\text {excess }}$ record from the sediment water interface to $7.2 \mathrm{mbsf}$ varies between -50 and 75 ppm (600 and $720 \mathrm{ppm}$ total $\mathrm{Ba}$ ), increasing at 2.6, 4, 5.1 and $5.6 \mathrm{mbsf}$ and decreasing at $2.1 \mathrm{mbsf}$ (Figure 1). A dramatic increase in $\mathrm{Ba}\left(200 \mathrm{ppm} \mathrm{Ba} \mathrm{Bexcss}_{\text {or }} 830 \mathrm{ppm}\right.$ total $\mathrm{Ba}$ ) occurs at $7.7 \mathrm{mbsf}$, with $\mathrm{Ba}_{\text {excess }}$ values peaking at $600 \mathrm{ppm}(1200 \mathrm{ppm}$ total $\mathrm{Ba})$ at $7.2 \mathrm{mbsf}$. This is the only region in the upper $15 \mathrm{~m}$ of the core where $\mathrm{Ba}_{\text {excess }}$ values exceed the entire regional detrital $\mathrm{Ba}$ range. Below this horizon to 15.5 mbsf $\mathrm{Ba}_{\text {excess }}$ falls to background levels, varying between -100 and $0 \mathrm{ppm}(530$ and $650 \mathrm{ppm}$ total $\mathrm{Ba}$ or 75 to $88 \mathrm{Ba} / \mathrm{Al}$ ), which is similar to the average regional detrital input [Dean et al., 1997]. Below the sediment depth (8 to $11 \mathrm{mbsf}$ ) of extreme $\mathrm{Ba}$ enrichment, $\mathrm{Ba}_{\text {excess }}$ values drop zero indicating only detrital $\mathrm{Ba}$ remains and elemental variations are likely related to changes in sediment provenance.

\section{Barium as a Productivity Indicator}

[11] Barium concentrations are enriched in sediments characterized by high concentrations of biogenic opal and
Corg [Bishop, 1988; Dehairs et al., 1987; Dymond and Collier, 1996; Goldberg and Arrhenius, 1958] and high barite concentrations are attributed to overlying productive surface waters [Gingele and Dahmke, 1994]. Profiles of dissolved $\mathrm{Ba}$ in the water column are characterized by a minimum in the nutrient-depleted euphotic zone and a steady increase with water depth [Jeandel et al., 1996; Monnin et al., 1999; Sternberg et al., 2008], whereas concentrations of particulate $\mathrm{Ba}$ are observed to increase just below the euphotic zone, decreasing slightly with water depth [Dehairs et al., 1980; Dymond and Collier, 1996; Sternberg et al., 2008]. It would appear that precipitation of marine barite occurs within or just below the euphotic zone and it undergoes gradual dissolution with depth. Laboratory and field experiments demonstrate that barite is rapidly produced in suspensions of decaying phytoplankton as a result of $\mathrm{Ba}$ release during the early stages of organic decay [Bishop, 1988; Ganeshram et al., 2003]. These mechanisms strongly support both the use of sedimentary $\mathrm{Ba}$ as a proxy for determining relative productivity changes through time, and thus the assumption that $\mathrm{Ba}_{\text {excess }}$ is equivalent to $\mathrm{Ba}_{\text {biogenic }}$.

[12] If all $\mathrm{Ba}_{\text {excess }}$ is assumed to be $\mathrm{Ba}_{\text {biogenic }}$ at ODP Hole $1017 \mathrm{E}$, then $\mathrm{Ba}_{\text {excess }}$ should be consistent with paleoproductivity reconstructions. A number of independent, coherent paleoproductivity proxies (e.g., \% upwelling species, \% carbonate carbon, \% opal, Corg/Al [Hendy et al., 2004]; Figure 2), exist for comparison. Productivity increased during warm climatic intervals including the Holocene and interstadial events, with the most pronounced interval of high productivity occurring during the Bølling. In sediments $<35$ ka intervals of increased productivity appear to correspond to low $\mathrm{Ba}_{\text {excess }}$ concentrations, while periods of decreased productivity appear to correspond to high $\mathrm{Ba}_{\text {excess }}$ in sediments. The interval of extreme Ba enrichment between 34 and 39 ka corresponds to minor productivity increases at Interstadial Events (IS) 7 and 8. From 40 to $60 \mathrm{ka}$, $\mathrm{Ba}_{\text {excess }}$ variations are insignificant and appear inconsistent with other productivity proxies. It is apparent from comparison between the records (Figure 2) that variability in the $\mathrm{Ba}_{\text {excess }}$ record at ODP Hole 1017E is not driven by changes in the productivity of the persistent upwelling cell off Point Conception. This result should be anticipated as the site is located nearshore within the OMZ.

\section{Detrital Sediment Provenance and Barium}

[13] Due to the nearshore location of ODP Hole 1017E, a significant detrital proportion of $\mathrm{Ba}$ in the sediments should be derived from terrigenous silicates, and Fe-Mn oxides and hydroxides. Delivery of detrital $\mathrm{Ba}$ to ODP Hole $1017 \mathrm{E}$ is predominantly from riverine input [Dean et al., 1997; Klump et al., 2000]; however, site is located offshore of a semiarid environment and therefore eolian deposition [Schroeder et al., 1997] cannot be excluded. Fe oxides efficiently scavenge dissolved species from seawater and as common components of eolian dust provide another Ba delivery mechanism to sediment [Schroeder et al., 1997], 20 to $40 \%$ of total $\mathrm{Ba}$ in some sediment is associated with aluminosilicate fractions [Gonneea and Paytan, 


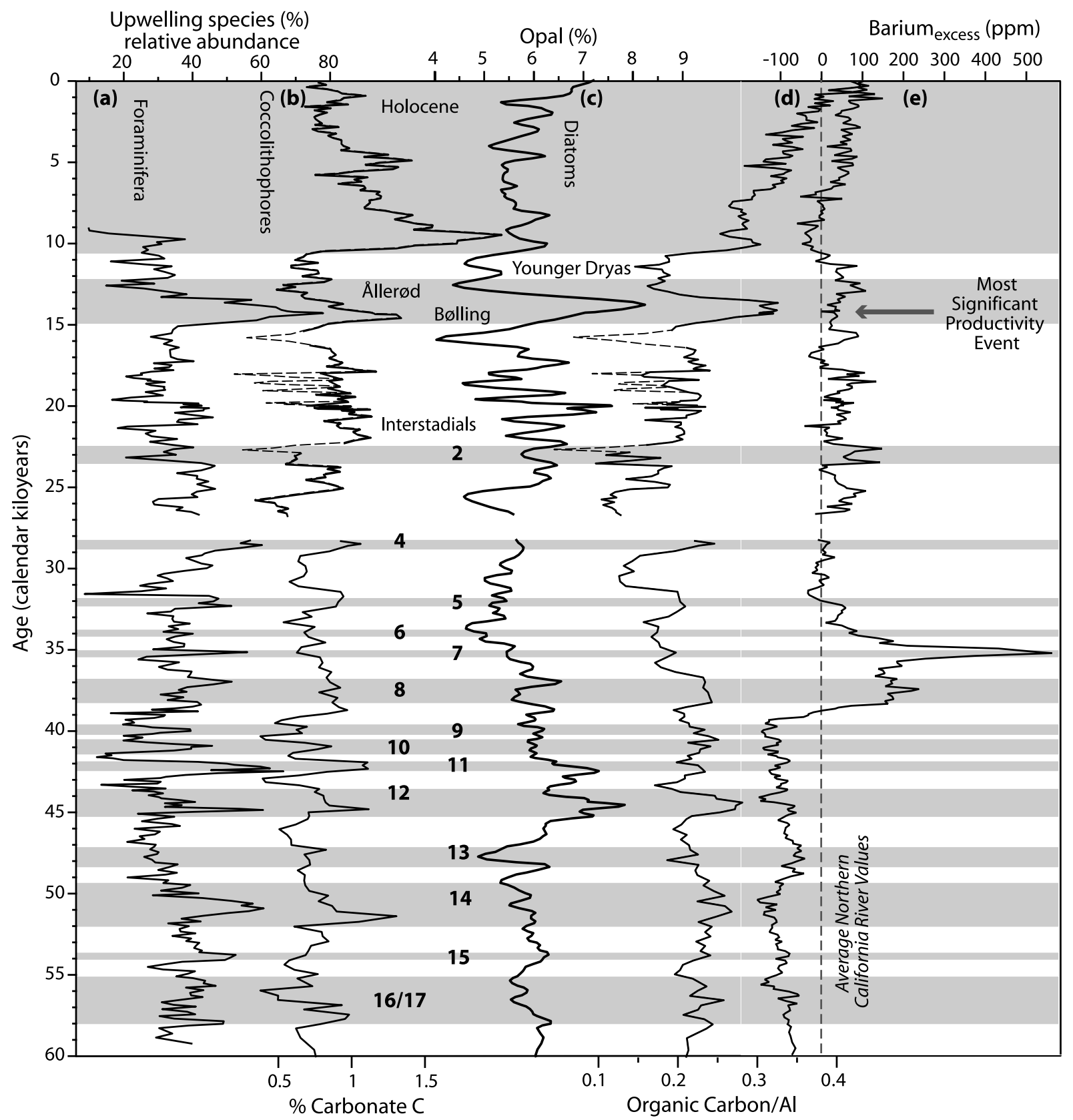

Figure 2. Comparison of proxy records associated with phytoplankton and zooplankton [Hendy et al., 2004] with barium. (a) The relative abundance (\%) of upwelling associated species G. quinqueloba and $G$. bulloides, (b) percent (\%) carbonate composition of the sediments, (c) percent (\%) opal (diatom) $_{\text {compo- }}$

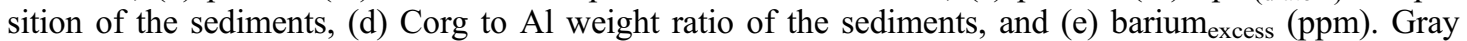
bands represent warm intervals (interstadials and the Holocene). Interstadials (D-O events) are numbered according to the GISP2 scheme with major climatic events labeled.

2006; Klump et al., 2000]. In this nearshore environment, variation in sediment provenance at the site may be as much as $60 \%$ of total $\mathrm{Ba}$ or $300 \mathrm{ppm}$ (see gray shading in Figures $1 \mathrm{c}$ and 1d). Thus much of the $\mathrm{Ba}$ variation downcore could be the result of changing detrital sediment provenance. The interval between 7 and $8 \mathrm{mbsf}(34$ to $40 \mathrm{ka})$, however, remains enriched in $\mathrm{Ba}$ beyond the highest regional detrital value.

\section{Barium and Barite Dissolution}

[14] It may be reasonable to assume that most $\mathrm{Ba}_{\text {excess }}$ is similar to $\mathrm{Ba}_{\text {biogenic }}$ in oxic depositional environments; 


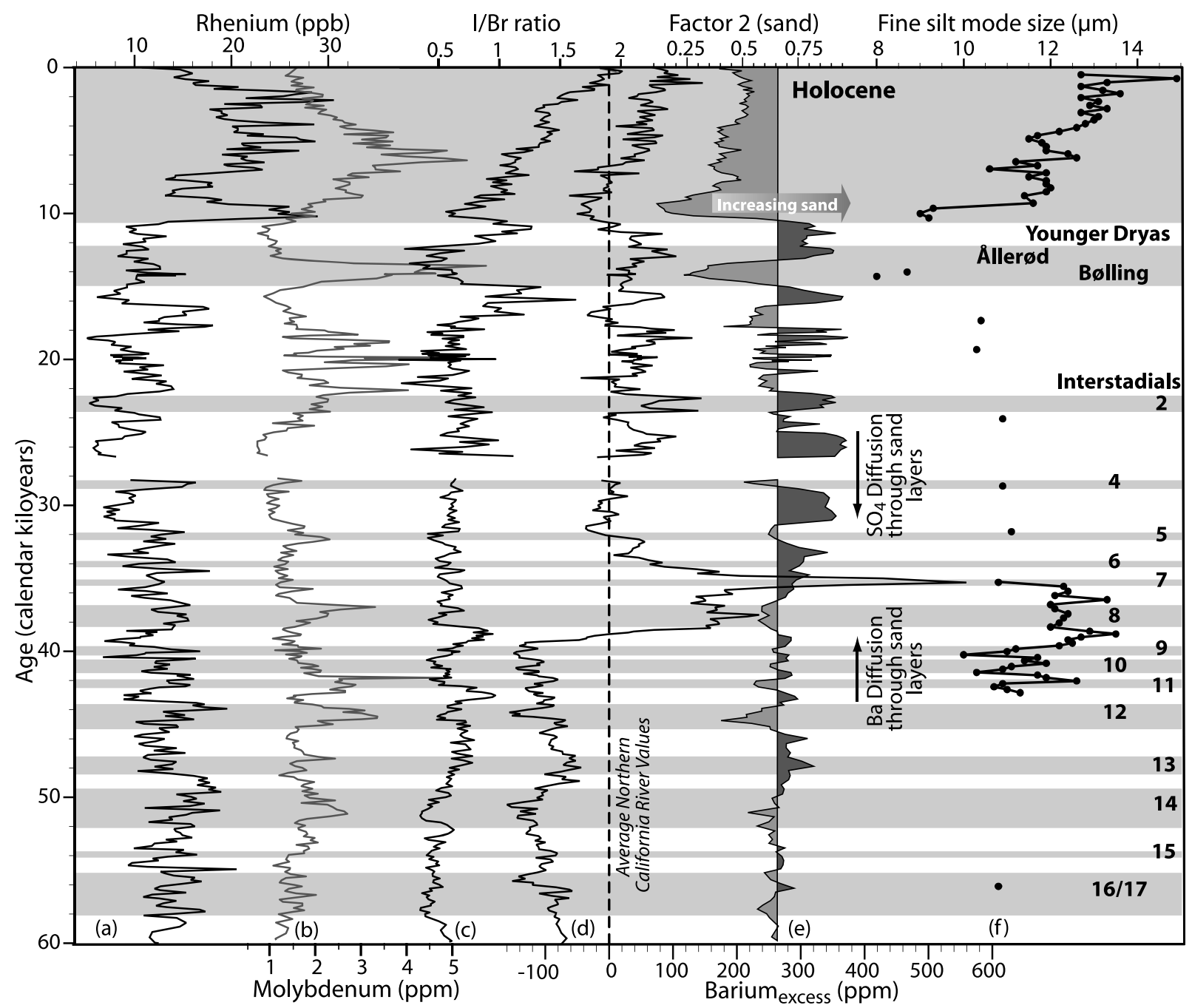

Figure 3. Comparison of redox indicators [Hendy and Pedersen, 2005] with barium. Suboxic indicators (a) rhenium (ppb), (b) molybdenum (ppm), (c) iodine/bromine ratio, and (d) barium excess (ppm) with sedimentary factors associated with (e) factor 2 (grain size [Hendy et al., 2004]), and (f) fine silt mode grain size [Tada et al., 2000]. Gray bands represent warm intervals (interstadials and the Holocene). Interstadials (D-O events) are numbered according to the GISP2 scheme with major climatic events labeled.

however, pore waters at ODP Hole 1017E are presently suboxic. Authigenic $\mathrm{Ba}$ in marine deposits occurs almost entirely as barite $\left(\mathrm{BaSO}_{4}\right)$, which although stable in oxygenated seawater, readily dissolves under sulfate-depleted conditions [Von Breymann et al., 1992]. High dissolved Ba concentrations in the upper few centimeters of marine sediment suggest that regeneration of $\mathrm{Ba}$ occurs within the upper few millimeters where maximum remineralization of Corg and other biogenic components occurs [Paytan and Kastner, 1996]. High benthic fluxes of dissolved Ba have been found in sediments underlying regions of high productivity in the pelagic realm [Paytan and Kastner, 1996] and in suboxic sediments [McManus et al., 1994].

[15] At ODP Hole 1017E, 95\% of the dissolved pore water oxygen is removed in the upper few centimeters of the sediments where trace metal diffusion and subsequent pre- cipitation in the sediments occurs. Similar redox conditions in the upper few centimeters of ODP Hole 1017E, appear to have prevailed throughout the Holocene and much of the Last Glacial as $\mathrm{Re}$ and $\mathrm{Mo}$ are consistently enriched (Figures 3a and 3b) [Hendy and Pedersen, 2005]. Notable exceptions occurred during stadial events prior to major interstadials (e.g., the Younger Dryas and prior to IS 11, IS 8, and the Bølling; Figure $3 \mathrm{c}$ ) when $\mathrm{I} / \mathrm{Br}$ ratios increase [Hendy and Pedersen, 2005]. Iodine enrichments relative to bromine indicate organic matter deposition under oxic bottom water conditions [Calvert and Pedersen, 1993]. Thus, during the aforementioned stadial intervals oxic conditions must have prevailed. $\mathrm{Ba}_{\text {excess }}$ increased during two of these intervals (just prior to the Bølling and during the Younger Dryas) coincident with increased $\mathrm{I} / \mathrm{Br}$ ratios [Hendy and Pedersen, 2005]. 
[16] The antiphase behavior of the $\mathrm{Ba}_{\text {excess }}$ record relative to the records of redox-sensitive trace metals such as Mo and $\mathrm{Re}$ indicates that the redox history of the site has compromised $\mathrm{Ba}_{\text {excess. }}$. Under these conditions $\mathrm{Ba}$ dissolves close to the sediment-water interface and is lost to the overlying water column. Examples of intervals where anoxic sediment conditions existed include; the early Holocene ( $8 \mathrm{ka}$ ), the Bølling (14.7 ka), 18 to $16 \mathrm{ka}$, and 22.5 to $20.5 \mathrm{ka}$. The reverse is true (i.e., increases in $\mathrm{Ba}_{\text {excess }}$ simultaneous with decreases in trace metals) during IS 2 , the LGM, just prior to the Bølling and during the Allerød and Younger Dryas (Figure 3). Yet, the period of extreme $\mathrm{Ba}$ enrichment between 36 and $34 \mathrm{ka}$ (IS 5 to 8 ) is different from these examples in that there is a concurrent increase, not a decrease, in the concentrations of redox-sensitive trace metals. Prior to $34 \mathrm{ka}$, the antiphase relationship between $\mathrm{Ba}_{\text {excess }}$ and redox-sensitive trace metals does not exist. It appears that the waxing and waning of the OMZ that controlled the shallow redox history at ODP Hole 1017E was not the only influence on $\mathrm{Ba}_{\text {excess }}$ at the site.

\section{Barium Remobilization and Diagenetic Fronts}

[17] Barite may also be formed by direct precipitation. When Ba-enriched hydrothermal fluids react with seawater sulfate massive barite deposits form, however, this mechanism is restricted to active hydrothermal regions (e.g., the East Pacific Rise [Feely et al., 1987]). Nonhydrothermal barite deposits also occur in layers or concretions in marine sediments. Massive sediment-hosted barite with no associated massive sulfide occurs in a variety of geologic settings and several diagenetic models have been proposed for the origin of these nonvolcanogenic barites. One favored mechanism for diagenetic barite formation is the remobilization of $\mathrm{Ba}_{\text {biogenic }}$ (in the presence of sulfate reduction) and subsequent precipitation at an authigenic front [Goldberg and Arrhenius, 1958; Torres et al., 1996].

[18] Below $8 \mathrm{mbsf}(38 \mathrm{ka})$ at ODP Hole 1017E, Ba $\mathrm{Bxcess}$ variations are muted and the values approach or fall below the detrital values suggesting little to no $\mathrm{Ba}_{\text {excess }}$ remains in the sediment. The apparent absence of barite in sediments older than $37 \mathrm{ka}$ suggests that at some point complete barite dissolution occurred. The extreme $\mathrm{Ba}_{\text {excess }}$ enrichment immediately above this zone of $\mathrm{Ba}_{\text {excess }}$ absence (i.e., 7-8 mbsf, 38-34 ka) is suggestive of barite precipitation at a diagenetic front. But what other evidence do we have for this authigenic front? Limited pore water studies at ODP Hole 1017E [Lyle et al., 1997] suggest that pore water $\mathrm{SO}_{4}^{2-}$ is almost completely depleted $(<10 \mu \mathrm{M})$ somewhere between 5.5 and $9.5 \mathrm{mbsf}$ (Figure 1e). By 19 mbsf, $\mathrm{SO}_{4}^{2-}$ is fully depleted and methanogenesis occurs [Lyle et al., 1997]. The major $\mathrm{Ba}_{\text {excess }}$ peak occurs within the interval of sulfate depletion (i.e., 6.5 to $8 \mathrm{mbsf}$ ) suggesting a linkage between the two.

[19] We hypothesize that $\mathrm{BaSO}_{4}$ dissolution in the sulfate-depleted interval below $\sim 8$ to $9 \mathrm{mbsf}$ resulted in upward diffusion of $\mathrm{Ba}^{2+}$ from the site of dissolution producing a pore water $\mathrm{Ba}$ gradient. Simultaneously, $\mathrm{SO}_{4}^{2-}$ migrates down from regions of high concentration in the upper core. Where dissolved $\mathrm{Ba}$ and $\mathrm{SO}_{4}^{2-}$ converge in the sediments, barite precipitates. Under conditions of ongoing sedimentation and geochemical steady state, continuous repetition of dissolution, diffusion, and precipitation will transport $\mathrm{Ba}$ progressively upward in the sediment profile and ultimately concentrate it into a thin layer at the top of the sulfate reduction zone [Gobeil et al., 1997]. A steeper $\mathrm{SO}_{4}^{2-}$ concentration gradient will yield a sharper diagenetic front [de Lange et al., 1994], and there is no downward migration of Ba by this mechanism [Gobeil et al., 1997].

[20] The depth of the Ba enrichment peak (Figure 3d) therefore demonstrates the vertical range of an active diagenetic front at ODP Hole 1017E. The modern sulfate depletion front is not, however, associated with redox sensitive metal enrichment because the significant burial depth of the front prevents trace metal diffusion from bottom waters. Most examples of barite fronts have been observed in deeply buried sediments [Riedinger et al., 2006; Torres et al., 1996]. However, one recent study found barite fronts at relatively shallow depth ( $\sim 4 \mathrm{mbsf})$ in association with burial of large amounts of organic matter under the Benguela upwelling system [Riedinger et al., 2006].

\section{Modern Authigenic Front and Submillennial Climate Change}

[21] The coincidence of the $\mathrm{Ba}_{\text {excess }}$ peak at $7.2 \mathrm{mbsf}$ with IS 7 (Figure 3d) may be highly suggestive of a climatic cause for the enrichment, but $\mathrm{Ba}_{\text {excess }}$ was not directly manipulated by submillennial climate change. A sediment facies change between stadial and interstadial (Figure 3) [Hendy et al., 2004; Tada et al., 2000] may have led to an indirect influence on $\mathrm{Ba}_{\text {excess. }}$. Increased Corg deposition occurred during interstadials when the local upwelling cell was active [Hendy et al., 2004]. Past productivity shifts and resulting changes in sedimentary Corg concentration are currently controlling the oxidant demand at depth at ODP Hole 1017E. High oxidant demand would result in a more rapid $\mathrm{SO}_{4}^{2-}$ reduction and upward migration of the active $\mathrm{SO}_{4}^{2-}$ depletion front within the diagenetic zone. Grain size also has a major affect on porosity and hence diffusion rates within the sediment. Fine grain sediment is less porous reducing diffusion rates, restricting $\mathrm{Ba}$ movement up-core and $\mathrm{SO}_{4}^{2-}$ down-core, and hence promoting precipitation of authigenic barite.

[22] Interstadials (IS) 5, 7 and 8 have major element sediment compositions indicative of low sand and high clay content, and the fine silt mode grain size decreases (Figures 3e and 3f) [Hendy et al., 2004]. There is a sharp increase in $\mathrm{Ba}_{\text {excess }}$ at IS 8 where dissolution of authigenic barite slows due to low diffusion rates of $\mathrm{SO}_{4}^{2-}$ out of the finegrained sediments of the interstadial and low oxidant demand in the Corg-poor sediments of the preceding stadial event. At the termination of IS 5, 6 and 7 there are sharp decreases in $\mathrm{Ba}_{\text {excess. }}$. Here authigenic barite formation is delayed by slow upward diffusion of $\mathrm{Ba}$ through the fine-grained sediment of IS 5 and 6, despite the $\mathrm{SO}_{4}^{2-}$-rich pore waters in the Corgpoor, coarse sediments of the following stadials. A potential future scenario could be that the sulfate depletion front will quickly diffuse upward through the Corg-poor, coarse sediment of younger stadial events before slowing again at a younger interstadial event (IS 4). Thus, it would appear that 
the paleoceanographic history of sediment deposition at the ODP Hole 1017E has preconditioned the position of an active diagenetic $\mathrm{Ba}$ front.

[23] Significant $\mathrm{Ba}_{\text {excess }}$ enrichments have been identified in sediments associated with past climatic change, and have been employed as indicators of increased export production [Bains et al., 2000; Brumsack, 2006; Paytan et al., 1996; Paytan et al., 2007; Weldeab et al., 2003]. As $\mathrm{Ba}$ is one of an elemental suite provided by commonly employed bulk sediment geochemistry techniques, interpretation of this element is easily incorporated into paleoceanographic studies. However, caution should be used when the Corg content of sediments increases dramatically or the oxygen concentration of overlying bottom waters decreases [Brumsack, 2006; McManus et al., 1998].

\section{Implications of the $B a_{\text {excess }}$ Record at Point Conception}

[24] The sedimentary record from ODP Hole 1017E serves as a warning for interpretation of $\mathrm{Ba}_{\text {excess }}$ as $\mathrm{Ba}$ biogenic in the geologic record. Knowledge of the depositional environment (nearshore and within the lower OMZ) would exclude this site as an appropriate location for $\mathrm{Ba}_{\text {excess }}$ use as a paleoproductivity proxy. Furthermore, although benthic foraminiferal assemblages [Cannariato and Kennett, 1999] and redox sensitive metals [Hendy and Pedersen, 2005] demonstrate that sulfide production occurred at the bottom water-sediment interface, indicators capable of identifying the deep diagenetic front within the core are less readily obtainable.

[25] Changes in OMZ strength, productivity and their associated proxies are decoupled from the Ba diagenetic front in both space $(\sim 7 \mathrm{mbsf})$ and time $(\sim 35 \mathrm{kyr})$. Trace metal enrichment and benthic foraminiferal assemblages temporally concurrent with the active diagenetic front are displaced $\sim 7 \mathrm{~m}$ up core. Trace metal enrichment and benthic foraminiferal assemblages that occur at the same stratigraphic depth and therefore are spatially congruent with the front were generated $35 \mathrm{kyr}$ before Ba precipitation at the front occurred. Thus, the benthic foraminiferal assemblage and trace metal concentration at ODP Hole 1017E are ineffective in identifying the origin of the most significant $\mathrm{Ba}$ enrichment (the modern mobile $\mathrm{Ba}$ diagenetic front) in the sediments at the site.

[26] The deep sulfate reduction front was identified by pore water analyses. Pore water analyses are destructive, requiring large amounts of sediment, and consequently are restrictive. Sulfur isotopes within the $\mathrm{Ba}_{\text {excess }}$ peak could identify the origin of $\mathrm{Ba}_{\text {excess }}$ within ODP Hole 1017E. Barite produced within the water column should have $\delta^{34} \mathrm{~S}$ values similar to seawater; however as microbial reduction of dissolved sulfate occurs, ${ }^{32} \mathrm{~S}$ enrichment in the newly formed $\mathrm{H}_{2} \mathrm{~S}$ should deplete the remaining pore water sulfate. Thus the $\delta^{34} \mathrm{~S}$ values of barite forming at the mobile $\mathrm{Ba}$ diagenetic front should be predictably high relative to $\mathrm{Ba}_{\text {biogenic }}$ [Paytan et al., 2002]. Finally as $\mathrm{Ba}_{\text {excess }}$ is suggested to overestimate $\mathrm{Ba}_{\text {biogenic }}$ due to the incorporation of terrigenous silicates [Eagle et al., 2003], it has been suggested that in environments where a significant detrital input occurs, a sequential extraction technique is required [Reitz et al., 2004]. This precludes new and increasingly employed analytical methods such as scanning XRF where bulk sediment $\mathrm{Ba}$ values are produced.

\section{Conclusions}

[27] ODP Hole 1017E, located beneath highly productive surface waters, provides an excellent opportunity to examine the burial, dissolution and precipitation of barite in marine sediment. In this location, high productivity as a result of persistent upwelling produces biogenic barite deposition. In the upper few $\mathrm{cm}$ of the sediment column, Corg degradation and low bottom water oxygen concentrations result in sulfate reduction, dissolving much of the $\mathrm{Ba}_{\text {biogenic }}$ and precipitating Re out of seawater. Consequently, throughout the upper $7 \mathrm{~m}$ of the core $\mathrm{Ba}_{\text {excess }}$ and $\mathrm{Re}$ are antiphase. This relationship changes within a zone of extreme $\mathrm{Ba}_{\text {excess }}$ between 38 and $34 \mathrm{ka}$ (IS 5 to 8 ) that directly overlies sediments where pore water sulfate is completely reduced and suggests that extreme $\mathrm{Ba}_{\text {excess }}$ enrichment is in fact a modern authigenic front. Changes in sediment grain size and Corg content, related to rapid climate and associated hydrographic change, appear to have preconditioned the position of the authigenic front. Thus, despite the significant temporal disconnect between rapid climate change events and the modern authigenic front, the two processes have become coupled. The results of this test case demonstrate that $\mathrm{Ba}_{\text {excess }}$ as a paleoproductivity proxy should be carefully assessed, particularly in nearshore highly productive ocean settings. Additional information on sedimentary redox conditions from pore water analysis, and/or sulfur isotopes should be provided in support of $\mathrm{Ba}_{\text {excess }}$ based paleoproductivity reconstructions.

\section{References}

Bains, S., R. D. Norris, R. M. Corfield, and K. L. Faul (2000), Termination of global warmth at the Palaeocene/Eocene boundary through productivity feedback, Nature, 407 (6801), 171-174, doi:10.1038/35025035.

Bishop, J. K. B. (1988), The barite-opal-organic carbon association in oceanic particulate matter, Nature, 332(6162), 341-343, doi:10.1038/ $332341 \mathrm{a} 0$.

Brumsack, H. J. (1986), The inorganic chemistry of Cretaceous black shales (DSDP Leg 41) in comparison to modern upwelling sediments from the Gulf of California, in North Atlantic Paleoceanography, edited by C. P. Summer- hayes and N. J. Shackleton, Geol. Soc. Spec. Publ., 21, 447-462.

Brumsack, H. J. (2006), The trace metal content of recent organic carbon-rich sediments: Implications for Cretaceous black shale formation, Palaeogeogr. Palaeoclimatol. Palaeoecol., 232(2-4), 344-361, doi:10.1016/j.palaeo. 2005.05.011.

Calvert, S. E. (1983), Elemental analyses, in Sedimentology, Physical Properties, and Geochemistry in the Initial Reports of the Deep Sea Drilling Project, edited by G. R. Heath, pp. 177-191, World Data Cent. for Geophys. and Mar. Geol., Boulder, Colo.
Calvert, S. E., and T. F. Pedersen (1993), Geochemistry of recent oxic and anoxic sediments: Implications for the geological record, Mar. Geol., 113, 67-88, doi:10.1016/0025-3227 (93)90150-T.

Cannariato, K. G., and J. P. Kennett (1999), Climatically related millennial-scale fluctuation in the strength of the California margin oxygen-minimum zone during the past $60 \mathrm{k}$.y. Geology, 27, 975-978, doi:10.1130/00917613(1999)027<0975:CRMSFI $>2.3 . \mathrm{CO} ; 2$

de Lange, G. J., B. van Os, P. A. Pruysers, J. J. Middelburg, D. Castradori, P. van Santvoort, P. J. Müller, H. Eggenkamp, and F. J. Prahl 
(1994), Possible early diagenetic alteration of paleo proxies, in Carbon Cycling in the Glacial Ocean: Constraints on the Ocean's Role in Global Change, edited by R. Zahn et al., NATO ASI Ser., Ser. I, 17, 225-258.

Dean, W. E., J. V. Gardner, and D. Z. Piper (1997), Inorganic geochemical indicators of glacial-interglacial changes in productivity and anoxia on the California continental margin, Geochim. Cosmochim. Acta, 61(21), 4507-4518, doi:10.1016/S0016-7037(97) 00237-8.

Dehairs, F., R. Chesselet, and J. Jedwab (1980), Discrete suspended particles of barite and barium cycle in the open ocean, Earth Planet. Sci. Lett., 49(2), 528-550, doi:10.1016/0012-821X (80)90094-1.

Dehairs, F., C. E. Lambert, R. Chesselet, and N. Risler (1987), The biological production of marine suspended barite and barium cycle in the western Mediterranean Sea, Biogeochemistry, 4(2), 119-140, doi:10.1007/BF02180151.

Dymond, J., and R. Collier (1996), Particulate barium fluxes and their relationships to biological productivity, Deep Sea Res., Part II, 43(4-6), 1283-1308, doi:10.1016/0967-0645 (96)00011-2.

Eagle, M., A. Paytan, K. R. Arrigo, G. van Dijken, and R. W. Murray (2003), A comparison between excess barium and barite as indicators of carbon export, Paleoceanography, 18(1), 1021, doi:10.1029/2002PA000793.

Feely, R. A., M. Lewison, G. J. Massoth, G. Robertbaldo, J. W. Lavelle, R. H. Byrne, K. L. Vondamm, and H. C. Curl (1987), Composition and dissolution of black smoker particulates from active vents on the Juan de Fuca Ridge, J. Geophys. Res., 92(B11), 11,347-11,363, doi:10.1029/JB092iB11p11347.

Ganeshram, R. S., R. Francois, J. Commeau, and S. L. Brown-Leger (2003), An experimental investigation of Barite formation in seawater, Geochim. Cosmochim. Acta, 67(14), 25992605, doi:10.1016/S0016-7037(03)00164-9.

Gingele, F., and A. Dahmke (1994), Discrete barite particles and barium as tracers of paleoproductivity in South Atlantic sediments, $\mathrm{Pa}$ leoceanography, 9(1), 151-168, doi:10.1029/ 93PA02559.

Gobeil, C., R. W. MacDonald, and B. Sundby (1997), Diagenetic separation of cadmium and manganese in suboxic continental margin sediments, Geochim. Cosmochim. Acta, 61 (21), 4647-4654, doi:10.1016/S0016-7037 (97)00255-X.

Goldberg, E. D., and G. O. S. Arrhenius (1958), Chemistry of Pacific pelagic sediments, Geochim. Cosmochim. Acta, 13(2-3), 153-212, doi:10.1016/0016-7037(58)90046-2.

Gonneea, M. E., and A. Paytan (2006), Phase associations of barium in marine sediments, Mar. Chem., 100(1-2), 124-135, doi:10.1016/ j.marchem.2005.12.003.

Hendy, I. L. (2010), The paleoclimatic response of the Southern Californian Margin to the rapid climate change of the last $60 \mathrm{Ka}$ : A regional overview, Quaternary Int., 215(1-2), 62-73, doi:10.1016/j.quaint.2009.06.009.

Hendy, I. L., and T. F. Pedersen (2005), Is pore water oxygen content decoupled from productivity on the California Margin? Trace element results from Ocean Drilling Program Hole 1017E, San Lucia slope, California, Paleoceanography, 20, PA4026, doi:10.1029/ 2004PA001123.

Hendy, I. L., J. P. Kennett, E. B. Roark, and B. L. Ingram (2002), Apparent synchroneity of sub- millennial scale climate events between Greenland and Santa Barbara Basin, California from 30-10 ka, Quat. Sci. Rev., 21(10), 1167-1184, doi:10.1016/S0277-3791(01)00138-X

Hendy, I. L., T. F. Pedersen, J. P. Kennett, and R. Tada (2004), Intermittent existence of a southern Californian upwelling cell during submillennial climate change of the last $60 \mathrm{kyr}$, Paleoceanography, 19, PA3007, doi:10.1029/ 2003PA000965.

Imbrie, J., and N. G. Kipp (1971), A new micropaleontology method for quantitative paleoclimatology: Application to a late Pleistocene Caribbean core, in Late Cenozoic Glacial Ages, edited by K. K. Turekian, pp. 71-181, Yale Univ. Press, New Haven, Conn

Irino, T., and T. Pedersen (2000), Geochemical character of glacial to interglacial sediments at Site 1017, Southern Californian Margin: Minor and trace elements, Proc. Ocean Drill. Program, Sci. Results, 167, 263-271.

Jeandel, C., B. Dupre, G. Lebaron, C. Monnin, and J. F. Minster (1996), Longitudinal distributions of dissolved barium, silica and alkalinity in the western and southern Indian Ocean, Deep Sea Res., Part I, 43(1), 1-31, doi:10.1016/ 0967-0637(95)00098-4.

Kennett, J. P., E. B. Roark, K. C. Cannariato, B. L Ingram, and R. Tada (2000), Latest Quaternary paleoclimatic and radiocarbon chronology, Hole 1017E, southern California margin, Proceedings of the Ocean Drilling Program, Scientific Results, 167, 249-254.

Klump, J., D. Hebbeln, and G. Wefer (2000), The impact of sediment provenance on barium-based productivity estimates, Mar. Geol., 169(3-4), 259-271, doi:10.1016/S0025-3227 (00)00092-X.

Leinen, M., and N. Pisias (1984), An objective technique for determining end-member compositions and for partitioning sediments according to their sources, Geochim. Cosmochim. Acta, 48(1), 47-62, doi:10.1016/0016-7037(84) 90348-X.

Lyle, M., I. Koizumi, and C. Richter (1997), Proceedings of the Ocean Drilling Program, Initial Reports, vol. 167, Ocean Drill. Program, College Station, Tex.

McManus, J., W. M. Berelson, G. P. Klinkhammer, T. E. Kilgore, and D. E. Hammond (1994), Remobilization of barium in continental margin sediments, Geochim. Cosmochim. Acta, 58(22), 4899-4907, doi:10.1016/0016-7037 (94)90220-8.

McManus, J., et al. (1998), Geochemistry of barium in marine sediments: Implications for its use as a paleoproxy, Geochim. Cosmochim. Acta, 62(21-22), 3453-3473, doi:10.1016/ S0016-7037(98)00248-8.

Monnin, C., C. Jeandel, T. Cattaldo, and F. Dehairs (1999), The marine barite saturation state of the world's oceans, Mar. Chem., 65(3-4), 253-261, doi:10.1016/S0304-4203 (99)00016-X.

Paytan, A., and E. M. Griffith (2007), Marine barite: Recorder of variations in ocean export productivity, Deep Sea Res., Part II, 54(5-7), 687-705, doi:10.1016/j.dsr2.2007.01.007.

Paytan, A., and M. Kastner (1996), Benthic Ba fluxes in the central equatorial Pacific, implications for the oceanic Ba cycle, Earth Planet. Sci. Lett., 142(3-4), 439-450, doi:10.1016/ 0012-821X(96)00120-3.

Paytan, A., M. Kastner, and F. P. Chavez (1996), Glacial to interglacial fluctuations in productivity in the equatorial Pacific as indicated by marine barite, Science, 274(5291), 1355-1357, doi:10.1126/science.274.5291.1355.

Paytan, A., S. Mearon, K. Cobb, and M. Kastner (2002), Origin of marine barite deposits: $\mathrm{Sr}$ and $\mathrm{S}$ isotope characterization, Geology, 30, 747-750, doi:10.1130/0091-7613(2002) 030<0747:OOMBDS $>2.0 . \mathrm{CO} ; 2$.

Paytan, A., K. Averyt, K. Faul, E. Gray, and E. Thomas (2007), Barite accumulation, ocean productivity, and $\mathrm{Sr} / \mathrm{Ba}$ in barite across the Paleocene-Eocene Thermal Maximum, Geology, 35, 1139-1142, doi:10.1130/G24162A.1.

Reitz, A., K. Pfeifer, G. J. de Lange, and J. Klump (2004), Biogenic barium and the detrital $\mathrm{Ba} / \mathrm{Al}$ ratio: A comparison of their direct and indirect determination, Mar. Geol., 204(3-4), 289-300, doi:10.1016/S0025-3227(04)00004-0.

Riedinger, N., S. Kasten, J. Groger, C. Franke, and K. Pfeifer (2006), Active and buried authigenic barite fronts in sediments from the Eastern Cape Basin, Earth Planet. Sci. Lett. 241(3-4), 876-887, doi:10.1016/j.eps1. 2005.10.032.

Schroeder, J. O., R. W. Murray, M. Leinen, R. C. Pflaum, and T. R. Janecek (1997), Barium in equatorial Pacific carbonate sediment: Terrigenous, oxide, and biogenic associations, Paleoceanography, 12(1), 125-146, doi:10.1029/ 96PA02736.

Seki, O., R. Ishiwatari, and K. Matsumoto (2002), Millennial climate oscillations in NE Pacific surface waters over the last $82 \mathrm{kyr}$ New evidence from alkenones, Geophys. Res. Lett., 29(23), 2144, doi:10.1029/ 2002 GL015200.

Steno, N., and J. G. Winter(1916), The Prodromus of Nicolaus Steno's Dissertation Concerning a Solid Body Enclosed by Process of Nature Within a Solid, vii, pp. 169-283, Macmillan, New York.

Sternberg, E., C. Jeandel, E. Robin, and M. Souhaut (2008), Seasonal cycle of suspended barite in the Mediterranean Sea, Geochim. Cosmochim. Acta, 72(16), 4020-4034, doi:10.1016 j.gca.2008.05.043.

Tada, R., S. Sato, T. Irino, H. Matsui, and J. P Kennett (2000), Millennial-scale compositional variations in Late Quaternary sediments at Site 1017, Southern California, Proc. Ocean Drill. Program, Sci. Results, 167, 277-296.

Torres, M. E., H. J. Brumsack, G. Bohrmann, and K. C. Emeis (1996), Barite fronts in continental margin sediments: A new look at barium remobilization in the zone of sulfate reduction and formation of heavy barites in diagenetic fronts, Chem. Geol., 127(1-3), 125-139, doi:10.1016/0009-2541(95)00090-9.

van Geen, A., R. G. Fairbanks, P. Dartnell, M. McGann, J. V. Gardner, and M. Kashgarian (1996), Ventilation changes in the northeast Pacific during the last deglaciation, Paleoceanography, 11(5), 519-528, doi:10.1029/ 96PA01860.

van Os, B. J. H., J. J. Middelburg, and G. J. Delange (1991), Possible diagenetic mobilization of barium in sapropelic sediment from the eastern Mediterranean, Mar. Geol., 100(1-4), 125-136, doi:10.1016/0025-3227 (91)90229-W.

Von Breymann, M. T., K. C. Emeis, and E. Suess (1992), Water depth and diagenetic constraints on the use of barium as a paleoproductivity indicator, in Upwelling Systems: Evolution Since the Early Miocene, edited by C. P. Summerhayes et al., Geol. Soc. Spec. Publ., 64, 273-284. 
Weldeab, S., K. C. Emeis, C. Hemleben, G. Schmiedl, and H. Schulz (2003), Spatial productivity variations during formation of sapropels S5 and S6 in the Mediterranean Sea: Evidence from Ba contents, Palaeogeogr. Palaeoclimatol. Palaeoecol., 191(2), 169-190, doi:10.1016/S0031-0182(02)00711-3.
Zheng, Y., A. v. Geen, R. Anderson, J. Gardner, and W. Dean (2000), Intensification of the northeast Pacific oxygen minimum zone during the Bølling/Ållerød warm period, Paleoceanography, 15(5), 528-536, doi:10.1029/ 1999PA000473.
I. L. Hendy, Department of Geological Sciences, University of Michigan, 1100 N. University Ave. Ann Arbor, MI 48109, USA. (ihendy@umich.edu) 